\title{
Splice-variant specific effects of a CACNA1H mutation associated with writer's cramp
}

\author{
Ivana A. Souza, Maria A. Gandini and Gerald W. Zamponi* (i)
}

\begin{abstract}
The CACNA1H gene encodes the a1 subunit of the low voltage-activated Ca $3.2 \mathrm{~T}$-type calcium channel, an important regulator of neuronal excitability. Alternative mRNA splicing can generate multiple channel variants with distinct biophysical properties and expression patterns. Two major splice variants, containing or lacking exon $26( \pm 26)$ have been found in different human tissues. In this study, we report splice variant specific effects of a Ca 3.2 mutation found in patients with autosomal dominant writer's cramp, a specific type of focal dystonia. We had previously reported that the R481C missense mutation caused a gain of function effect when expressed in $\mathrm{Ca}_{\mathrm{v}} 3.2(+26)$ by accelerating its recovery from inactivation. Here, we show that when the mutation is expressed in the short variant of the channel (-26), we observe a significant increase in current density when compared to wild-type Ca $3.2(-26)$ but the effect on the recovery from inactivation is lost. Our data add to growing evidence that the functional expression of calcium channel mutations depends on which splice variant is being examined.
\end{abstract}

Keywords: CACNA1H, Calcium channel, Ca 3.2 , Alternative splicing, Splice variant, Writer's cramp

The CACNA1H gene encodes the pore-forming $\alpha 1$ subunit of the $\mathrm{Ca}_{\mathrm{v}} 3.2$ calcium channel isoform which, along with $\mathrm{Ca}_{\mathrm{v}} 3.1$ (CACNA1G) and $\mathrm{Ca}_{\mathrm{v}} 3.3$ (CACNA1I), form the low-voltage activated T-type calcium channel family. The three isoforms generate currents with distinct biophysical and pharmacological properties and help regulate neuronal excitability, hormone secretion and cardiac function. Alternative mRNA splicing and differential splice-variant expression patterns further enhance the functional diversity of T-type channels [1].

Inherited or de novo mutations found in $\mathrm{Ca}_{\mathrm{v}} 3.2$ have been associated with numerous disorders, including epilepsy, primary aldosteronism, pain, autism and amyotrophic lateral sclerosis (for review see [2]). Many of these mutations have been characterized using heterologous expression systems and although a subset of these variants have been shown to cause significant biophysical

*Correspondence: zamponi@ucalgary.ca

Department of Physiology and Pharmacology, Hotchkiss Brain Institute, Cumming School of Medicine, Alberta Children's Hospital Research

Institute „, University of Calgary, Alberta, Calgary, Canada changes, some produce mild or no alterations of channel function. A few studies have pointed out that mutations may differentially affect the activity of different splice variants, which can partially explain the lack of effects seen in previous reports [3-6]. Another important consideration is that missense, silent and non-coding mutations that do not alter channel function can potentially contribute to disease by disturbing exonic splicing regulatory sites, thus affecting the normal expression of variants [7].

CACNA1H has been found to have at least 14 sites for alternative splicing with the potential to generate over 4,000 mRNA transcripts [7]. Two major splice variants, containing or lacking exon $26\left(\mathrm{Ca}_{\mathrm{v}} 3.2( \pm 26)\right)$ have been found in multiple human tissues (corresponding to exon 25 in rat that is expressed in roughly half of the channel transcripts in the thalamus [3]). The inclusion of exon 26 adds 6 amino acids to the cytoplasmic domain III-IV linker region of $\mathrm{Ca}_{\mathrm{v}} 3.2$ (Fig. 1a) and can cause changes in the biophysical properties of the channel, including a hyperpolarizing shift in the voltage dependence of activation and slower recovery from inactivation $[7,8]$. We have recently shown that a $\mathrm{R} 481 \mathrm{C} \mathrm{Ca} 3.2$ missense original author(s) and the source, provide a link to the Creative Commons licence, and indicate if changes were made. The images or other third party material in this article are included in the article's Creative Commons licence, unless indicated otherwise in a credit line to the material. If material is not included in the article's Creative Commons licence and your intended use is not permitted by statutory regulation or exceeds the permitted use, you will need to obtain permission directly from the copyright holder. To view a copy of this licence, visit http://creativecommons.org/licenses/by/4.0/. The Creative Commons Public Domain Dedication waiver (http://creativeco mmons.org/publicdomain/zero/1.0/) applies to the data made available in this article, unless otherwise stated in a credit line to the data. 


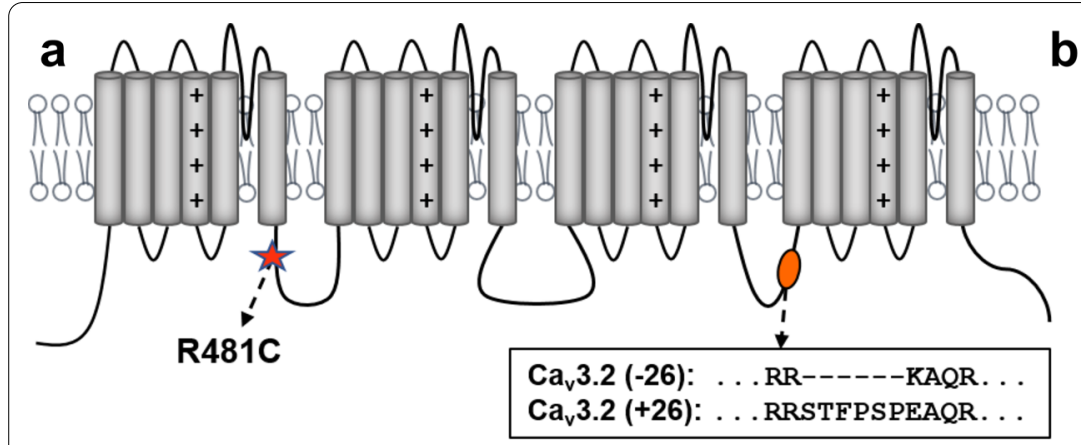

C

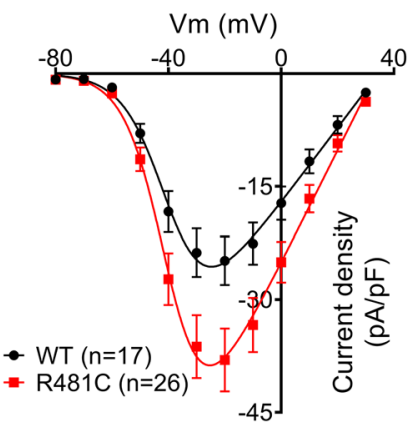

f

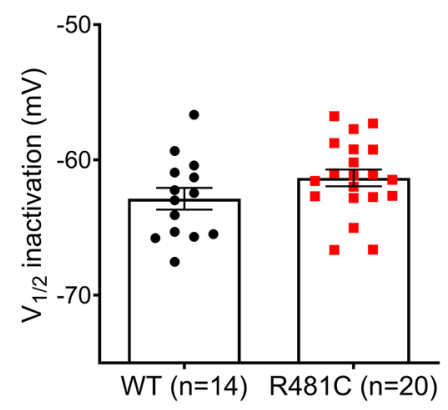

d

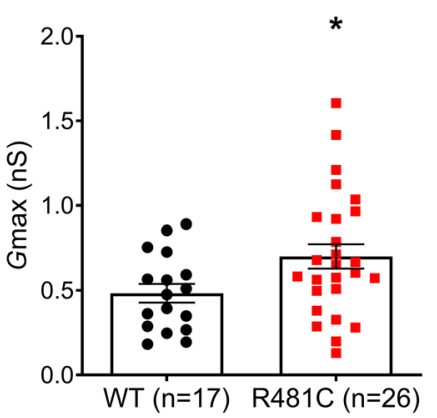

g

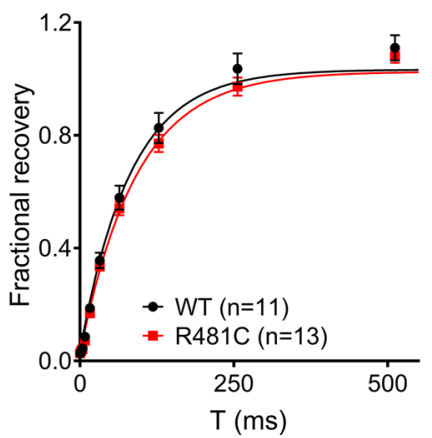

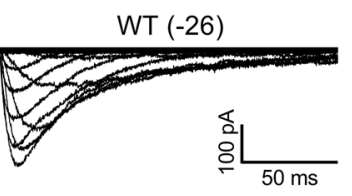

b

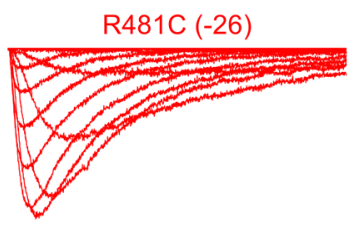

$\mathbf{e}$

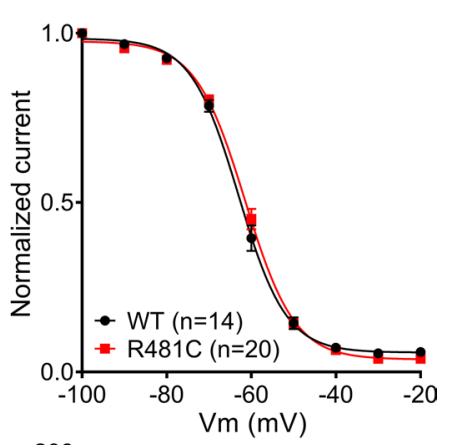

h

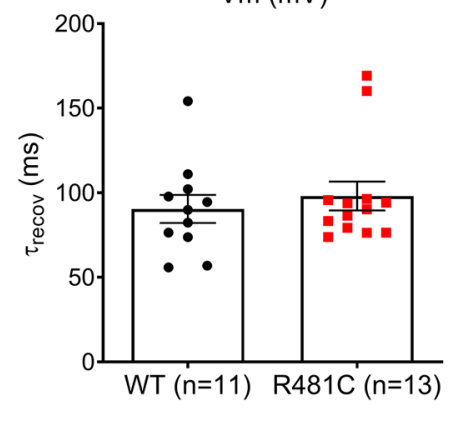

Fig. 1 Electrophysiological recordings from tsa-201 cells expressing wild-type and R481C mutant channels lacking exon $26\left(\mathrm{Ca}_{\mathrm{v}} 3.2(-26)\right)$. a Schematic representation of the $\mathrm{Ca}_{\mathrm{V}} 3.2$ channel a1 subunit showing the approximate location of the R481C mutation (I-II linker) and exon 26 (III-IV linker). b Representative $\mathrm{Ba}^{2+}$ current traces recorded from WT and R481C channels. c Average current densities (pA/pF) as a function of voltage showing an approximate $30 \%$ increase in current densities of mutant channels compared to WT. d Bar graph representing the corresponding maximum conductance $G_{\max }$. Values are represented as mean $\pm \mathrm{SEM}$. The asterisk denotes statistical significance relative to WT $\left({ }^{*} p=0.035\right.$, Student's t-test). e Steady-state inactivation curves for WT and R481C channels. f Mean half-inactivation potentials obtained from fits with the Boltzmann equation of individual steady-state inactivation curves. $\mathbf{g}$ Time course of recovery from inactivation for WT and R481C channels. $\mathbf{h}$ Time constant of recovery from inactivation obtained by individual fits of the recovery from inactivation data

variant that segregated in a family with autosomal dominant-inherited writer's cramp (WC) alters the biophysical properties of $\mathrm{Ca}_{\mathrm{v}} 3.2( \pm 26)$ channels. Electrophysiological analysis of $\mathrm{R} 481 \mathrm{C}$ cloned into $\mathrm{Ca}_{\mathrm{v}} 3.2(+26)$ showed that mutated channels had a significant faster recovery from inactivation when compared to wild-type (WT) $\mathrm{Ca}_{\mathrm{v}} 3.2$, while current density and steady-state inactivation properties remained the same [9]. Here, we tested the effects of this mutation in a channel backbone that lacks the exon 26 sequence in transfected tsA-201 cells. Figure $1 \mathrm{~b}$ shows representative $\mathrm{Ba}^{2+}$ current traces from WT and
$\mathrm{R} 481 \mathrm{C}$ channels. Different from what was seen in $\mathrm{Ca}_{\mathrm{v}} 3.2$ (+26), when $\mathrm{R} 481 \mathrm{C}$ was expressed in $\mathrm{Ca}_{\mathrm{v}} 3.2(-26)$, we noted a significant increase in current density as shown in the current density-voltage relationship and maximal conductance graphs (Fig. 1c, d). Steady state inactivation and recovery from inactivation properties were not different from WT channels (Fig. 1e-h). It is important to note that while the R481C mutation causes different effects depending on which splice variant is being tested, these effects imply a $\mathrm{Ca}_{\mathrm{v}} 3.2$ gain of function in both exon 26 containing and lacking channels, which can lead to 
increased neuronal excitability and contribute to a dystonic phenotype [10]. Although unlikely, it is unknown whether patients carrying the R481C mutation may also have alterations in exon 26 splicing that may exacerbate the effect of the mutations in specific tissues.

As mentioned above, splice variant specific effects of point mutations have previously been shown for $\mathrm{Ca}_{\mathrm{v}} 3.2$ channels. The R1584P mutation found in the genetic absence epilepsy rats from Strasbourg (GAERS) model only manifests itself functionally when introduced into the $\mathrm{Ca}_{\mathrm{v}} 3.2$ variant that carries exon 26 (exon 25 in rats) [3]. Point mutations associated with primary aldosteronism have also been shown to have splice variant specific effects. Three mutations (S196L, V1951E and P2083L) caused significant changes in $\mathrm{Ca}_{\mathrm{v}} 3.2(+26)$ but not in Ca 3.2 (-26) channels, while M1549I altered both channel splice variants function [6]. Interestingly, the authors of this study found that human zona glomerulosa cells, which produce the hormone aldosterone, only express the long $\mathrm{Ca}_{\mathrm{v}} 3.2(+26)$ channels. Since both splice variants are expressed in the brain, their results can partially explain why only patients with the M1549I mutation have neuronal abnormalities in addition to aldosteronism [6]. Splice variant specific effects of mutations have also been reported in the high-voltage activated $\mathrm{Ca}_{\mathrm{v}} 2.1 \mathrm{P} / \mathrm{Q}-$ type channels. Three type- 1 familial hemiplegic migraine (FHM-1) mutations alter channel function differently when expressed in $\mathrm{Ca}_{\mathrm{v}} 2.1$ containing or lacking exon 47 [4]. Our group has also reported an FHM-1 (Y1384C) mutation that has differential effects on recovery from inactivation dependent on which $\mathrm{Ca}_{\mathrm{v}} 2.1$ splice variant $( \pm 47)$ is being tested [5].

The R481C $\mathrm{Ca}_{\mathrm{v}} 3.2$ mutation has been previously found in a patient with bilateral trigeminal neuralgia [11]. This raises the question as to why identical mutations can generate distinct phenotypes in different patients. In fact, highly penetrant mutations for severe Mendelian diseases have been found in healthy individuals [12]. Considering the number of mRNA transcripts that $C A C$ $N A 1 H$ can generate, mutations can potentially produce different spatial and temporal effects depending on splice variant expression patterns. In addition, there is growing evidence suggesting the importance of other genes for the penetrance and expressivity of mutations [13]. Notably, besides the mutation in $C A C N A 1 H$, three additional missense mutations in other genes segregated with disease phenotype in the family affected with writer's cramp [9]. One of these genes, SPTBN5, encodes the protein spectrin- $\beta \mathrm{V}$, a member of the spectrin family of cytoskeletal proteins. Interestingly, our group has shown that $\mathrm{Ca}_{\mathrm{v}} 3.2$ channels interact and can be modulated by at least three spectrin proteins: spectrin- $\alpha \mathrm{II}$, spectrin- $\beta \mathrm{I}$ and spectrin- $\beta$ II [14]. Whether the mutation in the SPTBN5 gene affects the expression of the $\mathrm{R} 481 \mathrm{C}$ mutation in CACNA1H contributing to the pathophysiology of WC is unknown. Finally, we note that splicing of exon 26 interferes with calnexin-dependent retention of the channel in the ER, thus increasing channel expression at the cell surface [15]. It is possible that in $\mathrm{Ca}_{\mathrm{v}} 3.2(-26)$ channels, there is a synergistic effect between the domain I-II linker mutation and the enhanced ability of calnexin to facilitate ER export.

In conclusion, our study provides further evidence that CACNA1H alternative splicing may be important in the pathophysiology of genetic disorders and highlights complexity of the mechanisms by which a mutation can contribute to disease.

\section{Abbreviations}

RNA: Ribonucleic acid; mRNA: Messenger ribonucleic acid; WC: Writer's cramp; WT: Wild-type; GAERS: Genetic absence epilepsy rats from Strasbourg; FHM-1: Type-1 familial hemiplegic migraine.

\section{Acknowledgements}

We thank Lina Chen for technical support.

\section{Authors' contributions}

IAS co-designed the study, made the mutation, performed electrophysiological experiments and wrote the manuscript. MAG performed electrophysiological experiments. GWZ co-designed and supervised the study and edited the manuscript. All authors read and approved the final manuscript.

Funding

GWZ holds a Canada Research Chair and holds a CIHR Foundation grant.

\section{Availability of data and materials}

All data generated or analysed during this study are included in this published article.

\section{Declarations}

Ethics approval and consent to participate Not applicable.

\section{Consent for publication}

Not applicable.

\section{Competing interests}

The authors declare no competing interest.

Received: 26 August 2021 Accepted: 14 September 2021

Published online: 20 September 2021

\footnotetext{
References

1. Perez-Reyes E. Molecular physiology of low-voltage-activated T-type calcium channels. Physiol Rev. 2003;83(1):117-61.

2. Weiss N, Zamponi GW. Genetic T-type calcium channelopathies. J Med Genet. 2020;57(1):1-10.

3. Powell KL, Cain SM, Ng C, Sirdesai S, David LS, Kyi M, et al. A Cav3.2T-type calcium channel point mutation has splice-variant-specific effects on function and segregates with seizure expression in a polygenic rat model of absence epilepsy. J Neurosci. 2009;29(2):371-80.

4. Adams PJ, Garcia E, David LS, Mulatz KJ, Spacey SD, Snutch TP. Ca(V)2.1 P/Q-type calcium channel alternative splicing affects the functional
} 
impact of familial hemiplegic migraine mutations: implications for calcium channelopathies. Channels. 2009;3(2):110-21.

5. Gandini MA, Souza IA, Ferron L, Innes AM, Zamponi GW. The de novo CACNA1A pathogenic variant $Y 1384 C$ associated with hemiplegic migraine, early onset cerebellar atrophy and developmental delay leads to a loss of Cav2.1 channel function. Mol Brain. 2021;14(1):27.

6. He M, Xu Z, Zhang Y, Hu C. Splice-variant-specific effects of primary aldosteronism point mutations on human CaV3.2 calcium channels. Cell Calcium. 2019:84:102104.

7. Zhong X, Liu JR, Kyle JW, Hanck DA, Agnew WS. A profile of alternative RNA splicing and transcript variation of $C A C N A 1 H$, a human T-channe gene candidate for idiopathic generalized epilepsies. Hum Mol Genet. 2006;15(9):1497-512.

8. David LS, Garcia E, Cain SM, Thau E, Tyson JR, Snutch TP. Splice-variant changes of the $\mathrm{Ca}(\mathrm{V}) 3.2 \mathrm{~T}$-type calcium channel mediate voltagedependent facilitation and associate with cardiac hypertrophy and development. Channels. 2010;4(5):375-89.

9. Huang M, Nibbeling EAR, Lagrand TJ, Souza IA, Groen JL, Gandini MA, et al. Rare functional missense variants in $\mathrm{CACNA} 1 \mathrm{H}$ : What can we learn from Writer's cramp? Mol Brain. 2021:14(1):18

10. Stahl CM, Frucht SJ. Focal task specific dystonia: a review and update. J Neurol. 2017:264(7):1536-41.
11. Dong W, Jin SC, Allocco A, Zeng X, Sheth AH, Panchagnula S, et al. Exome Sequencing Implicates Impaired GABA Signaling and Neuronal Ion Transport in Trigeminal Neuralgia. iScience. 2020;23(10):101552.

12. Chen R, Shi L, Hakenberg J, Naughton B, Sklar P, Zhang J, et al. Analysis of 589,306 genomes identifies individuals resilient to severe Mendelian childhood diseases. Nat Biotechnol. 2016;34(5):531-8.

13. Kammenga JE. The background puzzle: how identical mutations in the same gene lead to different disease symptoms. FEBS J. 2017:284(20):3362-73.

14. Garcia-Caballero A, Zhang FX, Hodgkinson V, Huang J, Chen L, Souza IA, et al. T-type calcium channels functionally interact with spectrin (alpha/ beta) and ankyrin B. Mol Brain. 2018;11(1):24

15. Proft J, Rzhepetskyy Y, Lazniewska J, Zhang FX, Cain SM, Snutch TP, et al. The Cacna1h mutation in the GAERS model of absence epilepsy enhances T-type Ca2 + currents by altering calnexin-dependent trafficking of Cav3.2 channels. Sci Rep. 2017;7(1):11513.

\section{Publisher's Note}

Springer Nature remains neutral with regard to jurisdictional claims in published maps and institutional affiliations.
Ready to submit your research? Choose BMC and benefit from:

- fast, convenient online submission

- thorough peer review by experienced researchers in your field

- rapid publication on acceptance

- support for research data, including large and complex data types

- gold Open Access which fosters wider collaboration and increased citations

- maximum visibility for your research: over $100 \mathrm{M}$ website views per year

At BMC, research is always in progress.

Learn more biomedcentral.com/submissions 